\title{
PENGARUH PERSEPSI WAJIB PAJAK TENTANG PENERAPAN PP NO. 46 TAHUN 2013, PEMAHAMAN PERPAJAKAN, DAN SANKSI PERPAJAKAN TERHADAP KEPATUHAN WAJIB PAJAK USAHA MIKRO, KECIL, DAN MENENGAH DI KOTA YOGYAKARTA
}

\author{
Zaen Zulhaj Imaniati \\ Akuntansi Universitas Negeri Yogyakarta \\ ziezulhaj@yahoo.co.id
}

\author{
Isroah \\ Staf Pengajar Jurusan Pendidikan Akuntansi Universitas Negeri Yogyakarta
}

\begin{abstract}
Abstrak : Pengaruh Persepsi Wajib Pajak Tentang Penerapan PP No. 46 Tahun 2013, Pemahaman Perpajakan, Dan Sanksi Perpajakan Terhadap Kepatuhan Wajib Pajak Usaha Mikro, Kecil, Dan Menengah Di Kota Yogyakarta. Penelitian ini bertujuan untuk mengetahui Pengaruh: (1) Persepsi Wajib Pajak Tentang Penerapan PP No. 46 tahun 2013 terhadap Kepatuhan Wajib Pajak UMKM, (2) Pemahaman Perpajakan terhadap Kepatuhan Wajib Pajak UMKM, (3) Sanksi Perpajakan terhadap Kepatuhan Wajib Pajak UMKM, serta (4) Persepsi Wajib Pajak Tentang Penerapan PP No. 46 Tahun 2013, Pemahaman Perpajakan, dan Sanksi Perpajakan secara bersamasama terhadap Kepatuhan Wajib Pajak Usaha Mikro, Kecil, dan Menengah (UMKM) di Kota Yogyakarta. Teknik analisis data menggunakan uji prasyarat analisis data dan uji hipotesis. Hasil penelitian ini menunjukkan: persepsi wajib pajak tentang penerapan PP No. 46 tahun 2013 berpengaruh positif dan signifikan terhadap kepatuhan wajib pajak UMKM, ditunjukkan dengan angka koefisien regresi bernilai positif yaitu 0,582 dan $t$ hitung 3,071 > t tabel 1,66123. Pemahaman perpajakan berpengaruh positif dan signifikan terhadap kepatuhan wajib pajak UMKM, diunjukkan dengan nilai koefisien regresi bernilai positif yaitu 0,708 dan t hitung 5,894 > t tabel 1,66123. Sanksi perpajakan berpengaruh positif dan signifikan terhadap kepatuhan wajib pajak UMKM, ditunjukkan dengan nilai koefisien regresi bernilai positif yaitu 1,066 dan t hitung 3,746 > t tabel 1,66123. Persepsi wajib pajak tentang penerapan PP No. 46 tahun 2013, pemahaman perpajakan, dan sanksi perpajakan berpengaruh positif dan signifikan secara bersama-sama terhadap kepatuhan wajib pajak UMKM. Hal tersebut dibuktikan dari nilai koefisien regresi yang bernilai positif yaitu 0,$278 ; 0,726 ; 0,497$ dan nilai $\mathrm{F}$ hitung $12,761>$ F tabel 1,66123.
\end{abstract}

Kata Kunci: Kepatuhan Wajib Pajak, Persepsi Wajib Pajak Tentang Penerapan PP No. 46 Tahun 2013, Pemahaman Perpajakan, Sanksi Perpajakan.

Abstract: The Influence Of The Perception Of Taxpayers About Implementation Of Pp No. 46 Tahun 2013 And The Understanding Of Taxation And Tax Penalties On Tax Compliance Of Micro Small And Medium Enterprises In The City Of Yogyakarta. The purpose of this study was to determine the influence of: (1) The Perception Of Taxpayers About Implementation Of PP No. 46 Tahun 2013 for tax compliance of MSMEs, (2) the understanding of taxation for tax compliance of MSMEs, (3) Tax penalties for tax compliance of MSMEs, and also (4) The Perception Of Taxpayers About Implementation Of PP No. 46 Tahun 2013 And The Understanding Of Taxation And Tax Penalties together on Tax Compliance of MSMEs. The method of data analysis used were prerequisite data analysis test and hypothesis test. The result of the research shows The Perception Of Taxpayers About Implementation Of PP No. 46 Tahun 2013 positively influance and the significance towards the tax compliance. It is proved that the regression coefficient is positive 0,582 and t count 3,071 > t table 1,66123. The understanding of taxation positively influence and significant toward the tax compliance. It is proved that the the regression coefficient is positive 0,708 and t count 5,894 >t table 1,66123. Tax penalties positively influence and significant toward the tax compliance. It is proved that the regression coefficient is positive 1,066 and t count 3,746 > t table 1,66123. The Perception Of Taxpayers About Implementation Of PP No. 46 Tahun 2013, the understanding taxation and tax penalties positively together influenced toward the tax compliance. It is proved that the regression coefficient is positive 0,278; 0,726; 0,497 and $F$ count 12,761 > F table 1,6612). 
Keywords: Tax Compliance, The Perception Of Tax payers About Implementation Of PP No. 46 Tahun 2013, The Understanding of Taxation, Tax Penalties.

\section{PENDAHULUAN}

Suatu negara dalam menjalankan pemerintahan dan pembangunan membutuhkan dana yang tidak sedikit. Dana tersebut dapat diperoleh dari sumber dalam negeri maupun luar negeri. Salah satu cara untuk memperoleh dana yaitu dengan pemungutan pajak. Pajak merupakan penerimaan dana yang paling aman dan handal karena bersifat fleksibel, lebih mudah dipengaruhi melalui kebijakan negara yang bersangkutan. Pajak merupakan sumber penerimaan terbesar bagi negara. Setiap tahun pendapatan pemerintah dari pajak mengalami peningkatan. Peningkatan pendapatan tersebut diimbangi dengan pengupayaan pemerintah dalam berbagai kebijakan yang meningkatkan kesadaran wajib pajak dalam memenuhi kewajibannya. Berbagai peraturan baru semakin banyak dikeluarkan dengan harapan masyarakat dapat berpartisipasi aktif dalam memenuhi kewajiban perpajakan.

Saat ini pemerintah mulai melirik sektor swatsa yang dipastikan memiliki potensi besar untuk pemasukan pajak. Sektor tersebut adalah Usaha Mikro, Kecil, dan Menengah (UMKM). UMKM memiliki omset dan laba yang jauh lebih kecil dibandingkan dengan perusahaanperusahaan besar. Berdasarkan survei BPS,
UMKM menyumbang 57\% untuk Produk Domestik Bruto (PDB) sedangkan kontribusi UMKM terhadap pajak hanya sebesar 5\%. Upaya untuk meningkatkan pemenuhan perpajakan secara sukarela (voluntary tax compliance) dan mendorong kontribusi penerimaan negara dari sektor UMKM, pemerintah telah menerbitkan Peraturan Pemerintah Nomor 46 Tahun 2013 tentang Pajak Penghasilan atas penghasilan dari usaha yang diterima atau diperoleh wajib pajak yang memiliki peredaran bruto tertentu. Penerapan PP No. 46 Tahun 2013 bertujuan untuk memberikan kemudahan dan penyederhanaan perpajakan, memberikan edukasi masyarakat untuk tertib administrasi, memberikan edukasi masyarakat untuk transaparansi, dan memberikan kesempatan masyarakat untuk berkonstribusi dalam penyelenggaraan negara. Peraturan Perpajakan yang baru ini memiliki kelebihan yaitu tarif yang dianut lebih kecil dari tarif yang sebelumnya yaitu $1 \%$ dari omset. PP No.46 Tahun 2013 berlaku untuk Wajib Pajak Orang pribadi dan/atau Badan yang memiliki penghasilan bruto tertentu, yaitu penghasilan yang kurang dari 4,8 $\mathrm{M}$ terbatas pada penghasilan dari usaha.

Penerapan PP No. 46 Tahun 2013 ini menimbulkan pro dan kontra. Pemerintah berniat untuk memberikan kemudahan dan 


\section{JURNAL NOMINAL / VOLUME V NOMOR 2 / TAHUN 2016}

penyederhanaan aturan perpajakan serta memberikan kemudahan

dan

penyederhanaan dalam penyelenggaraan negara sepertinya tidak disambut dengan baik bagi masyarakat. Berdasarkan penelitian yang dilakukan oleh Gandhys Resynar (2014) mayoritas para pelaku UMKM tidak setuju dengan penerapan PP No. 46 Tahun 2013 karena jumlah pajak yang dibayar lebih besar. Tetapi persepsi wajib pajak terhadap PP No.46 Tahun 2013 mengenai fasilitas kemudahan dan penyederhanaan perpajakan mayoritas pelaku UMKM setuju bahwa PP No. 46 Tahun 2013 membawa kemudahan dan penyederhaan.

Berdasarkan penelitian yang dilakukan Adi Ratno Pamuji, dkk (2014) terdapat beberapa faktor yang mempengaruhi kepatuhan wajib pajak UMKM. Faktorfaktor yang mempengaruhi tersebut adalah pemahaman perpajakan, pengawasan, dan sosialisasi. Berdasarkan penelitian Arabella dan Yenni (2013) menyatakan bahwa kepatuhan wajib pajak UMKM dipengaruhi oleh kualitas pelayanan petugas pajak dan sanksi perpajakan.

Dalam pelaksanaan self assessment system hal yang diharapkan ada pada diri wajib pajak yaitu kesadaran wajib pajak, kejujuran wajib pajak, kemauan untuk membayar pajak, disiplin wajib pajak terhadap pelaksanaan peraturan perpajakan. Melalui sistem tersebut diharapkan dapat dilaksanakannya administrasi perpajakan dengan lebih mudah, jelas, tertib, efektif, efisien dan terkendali.

Wajib pajak akan memenuhi kewajibannya jika wajib pajak tersebut memahami ketentuan umum dan tata cara perpajakan yang ada di Indonesia. Di Indonesia, belum semua wajib pajak memiliki pengetahuan dan memahami perpajakan secara baik. Hal ini dapat dilihat dari wajib pajak belum memahami SPT Tahunan. Wajib pajak masih melakukan kesalahan dalam pengisian SPT Tahunan padahal KPP sudah menyediakan buku panduan yang akan memudahkan wajib pajak dalam mengisi SPT Tahunan. Pemahaman perpajakan diperlukan untuk memudahkan wajib pajak dalam mematuhi kewajiban perpajakannya. Pemahaman perpajakan meliputi perhitungan pajak, penyetoran pajak, pelaporan pajak, dan pengisian SPT. Semua itu dapat dilakukan oleh wajib pajak secara mudah jika wajib pajak memiliki pemahaman tentang perpajakan yang berlaku.

Usaha untuk meningkatkan kepatuhan UMKM dalam membayar pajak pemerintah juga telah menyediakan sanksi perpajakan bagi wajib pajak yang tidak membayar pajak. Pada tahun 2015, pemerintah memberikan fasilitas perpajakan berupa penghapusan sanksi administrasi perpajakan. Sanksi administrasi yang dihapuskan adalah sanksi yang timbul akibat pelaporan, pembetulan, pembayaran SPT Tahunan Pajak Penghasilan 


\section{JURNAL NOMINAL / VOLUME V NOMOR 2 / TAHUN 2016}

Tahun Pajak 2014 dan sebelumnya dan/atau SPT Masa Desember 2014 dan sebelumnya yang dilakukan di tahun 2015. Wajib pajak diberikan pengampunan atas kelalaian mereka dalam melaporkan pajak seperti kurang bayar dan tidak bayar. Pemberian fasilitas ini dimanfaatkan oleh wajib pajak sehingga banyak wajib pajak melaporkan pajak yang sebelumnya tidak pernah dilaporkan. Hal tersebut membuktikan bahwa wajib pajak tidak melaporkan pajak karena memiliki ketakutan terhadap sanksi yang akan diterima apabila melanggar peraturan pajak.

Berdasarkan uraian di atas, maka peneliti tertarik untuk melakukan penelitian tentang kepatuhan wajib pajak. Penelitian ini dikhususkan bagi kepatuhan wajib pajak UMKM yang ada di Kota Yogyakarta. Hal ini dikarenakan Kota Yogyakarta merupakan daerah yang cukup banyak penyebaran UMKMnya. UMKM di Kota Yogyakarta bergerak dalam berbagai bidang tetapi berdasarkan informasi yang dibaca peneliti menyatakan bahwa banyak yang tidak memenuhi kepatuhan wajib pajak. Penelitian ini berjudul "Pengaruh Persepsi Wajib Pajak tentang Penerapan PP No. 46 Th 2013, Pemahaman Perpajakan, dan Sanksi Perpajakan Terhadap Kepatuhan Wajib Pajak Usaha Mikro, Kecil, dan Menengah Di Kota Yogyakarta”.

\section{METODE PENELITIAN}

Jenis Penelitian

Penelitian ini merupakan jenis penelitian kausal komparatif dengan pendekatan kuantitatif.

\section{Waktu dan Tempat Penelitian}

Penelitian ini dilaksanakan pada bulan Maret sampai April 2016. Penelitian ini dilakukan di UMKM Kota Yogyakarta.

\section{Populasi dan Sampel Penelitian}

Populasi dalam penelitian ini adalah seluruh wajib pajak UMKM di Kota Yogyakarta. Sampel yang didapat dari perhitungan yaitu sebanyak 95 unit UMKM di Kota Yogyakarta.

\section{Prosedur}

Data diperoleh dengan memberikan angket atau kuesioner kepada responden. Penelitian ini menggunakan angket tertutup yaitu angket yang menghendaki jawaban singkat tentang diri responden dan jawabannya sudah disediakan oleh peneliti sehingga responden hanya tinggal memilih. Pembagian kuesioner atau angket penelitian dilakukan oleh peneliti kepada wajib pajak UMKM yang ada di Kota Yogyakarta.

Data, Instrumen, dan Teknik Analisis Data

\section{Data dan Instrumen}

Data penelitian ini adalah data primer. Perolehan data dilakukan dengan menyebar kuesioner kepada UMKM yang ada di Kota Yogyakarta. Penelitian ini menggunakan 
instrumen angket atau kuesioner. Data dikumpulkan dari para responden dengan menggunakan kuesioner dengan Skala Likert yang nantinya digunakan untuk mengukur Kepatuhan Wajib Pajak UMKM, Penerapan PP 46 tahun 2013, Pemahaman Perpajakan, dan Sanksi Perpajakan. Instrumen penelitian terlebih dahulu dilakukan uji validitas dan uji reliabilitas. Uji instrumen yang dilakukan oleh peneliti merupakan uji terpakai.

\section{Teknik Analisis Data}

Penelitian ini menggunakan data primer dengan menyebarkan kuesioner ke UMKM. Setelah data diperoleh, peneliti melakukan uji instrumen. Uji instrumen yang digunakan adalah uji terpakai. Uji instrumen meliputi uji validitas data dan uji reliabilitas data. Metode analisis data yang digunakan yaitu analisis statistik deskriptif. Kemudian uji prasyarat analisis yang terdiri dari uji normalitas, uji linieritas, uji heteroskedastisitas, dan uji multikolinieritas. Uji hipotesis menggunakan uji regresi linier sederhana dan uji regresi linier berganda.

\section{HASIL PENELITIAN}

PEMBAHASAN

\section{Statistik Deskriptif}

Responden dalam penelitian ini berjumlah 95 unit UMKM di Kota Yogyakarta. Analisis statistik deskriptif yang disajikan dalam penelitian ini meliputi Nilai Minimum, Nilai Maximum, Mean (M), dan Standar Deviasi (SD).
Tabel 1. Hasil Analisis Deskriptif

\begin{tabular}{ccccc}
\hline KET & $\mathbf{Y}$ & $\mathbf{X}_{\mathbf{1}}$ & $\mathbf{X}_{\mathbf{2}}$ & $\mathbf{X}_{\mathbf{3}}$ \\
\hline Min & 21 & 24 & 20 & 14 \\
\hline Max & 44 & 37 & 40 & 23 \\
\hline M & 34,94 & 30,40 & 30,58 & 17,83 \\
\hline SD & 5,8884 & 3,068 & 4,333 & 1,998 \\
\hline
\end{tabular}

Sumber: Data yang diolah 2016.

\section{Uji Prasyarat Analisis}

\section{a. Uji Normalitas Data}

Hasil uji normalitas dapat dilihat pada tabel dibawah ini. Nilai KolmogorovSmirnov $Z$ sebesar 0,832 dengan nilai signifikansi (Asymp. Sig. 2-tailed) 0,493. Signifikansi lebih dari 0,05 maka dapat disimpulkan data tersebut berdistribusi normal.

Tabel 2. Hasil Uji Normalitas

One-Sample Kolmogorov-Smirnov Test

\begin{tabular}{|c|c|c|}
\hline & $\begin{array}{c}\text { Unstandardized } \\
\text { Residual }\end{array}$ \\
\hline \multicolumn{2}{|c|}{$\mathrm{N}$} & 95 \\
\hline \multirow{2}{*}{$\begin{array}{c}\text { Normal } \\
\text { Parameters }{ }^{\mathrm{a}} \text {, } \\
\text { b }\end{array}$} & Mean & $0 \mathrm{E}-7$ \\
\hline & Std. Deviation & 4,93678337 \\
\hline Most & Absolute & ,085 \\
\hline Extreme & Positive & ,085 \\
\hline Differences & Negative &,- 044 \\
\hline \multicolumn{2}{|c|}{ Kolmogorov-Smirnov Z } & ,832 \\
\hline \multicolumn{2}{|c|}{ Asymp. Sig. (2-tailed) } & ,493 \\
\hline
\end{tabular}

\section{b. Uji Linieritas}

Hasil uji linieritas dapat ditunjukkan pada tabel dibawah ini: 


\section{JURNAL NOMINAL / VOLUME V NOMOR 2 / TAHUN 2016}

Tabel 3. Hasil Uji Linieritas

\begin{tabular}{cc}
\hline Variabel & $\begin{array}{c}\text { Deviation from } \\
\text { Linearity }\end{array}$ \\
\hline $\mathbf{Y} * \mathbf{X} 1$ & 0,125 \\
\hline $\mathbf{Y} * \mathbf{X} 2$ & 0,140 \\
\hline $\mathbf{Y} * \mathbf{X} 3$ & 0,211
\end{tabular}

Sumber: Data yang diolah 2016

Nilai Deviation from Linearity lebih besar dari 0,05 maka dapat disimpulkan bahwa pengaruh masing-masing variabel independen terhadap variabel dependen bersifat linier.

\section{Uji Asumsi Klasik}

\section{a. Uji Heteroskedastisitas}

Hasil Uji Heteroskedastisitas dapat dilihat pada tabel dibawah ini:

Tabel 4. Hasi Uji Heteroskedastisitas

\begin{tabular}{cc}
\hline Model & Sig. \\
\hline X1 & 0,677 \\
\hline X2 & 0,667 \\
\hline X3 & 0,840
\end{tabular}

Sumber: Data yag diolah 2016

Berdasarkan tabel diatas, dapat disimpulkan bahwa variabel bebas yang digunakan tidak terjadi heteroskedastisitas. Hal ini dapat dilihat dari nilai signifikansi variabel bebas yang melebihi 0,05 .

\section{b. Uji Multikolinieritas}

Hasil uji multikoliniertitas dapat dilihat pada tabel dibawah ini:
Tabel 5. Hasil Uji Multikolinieritas

\begin{tabular}{lcc}
\hline \multirow{2}{*}{ Model } & \multicolumn{2}{c}{ Collinearity Statistics } \\
\cline { 2 - 3 } & Tolerance & VIF \\
\hline (Constant) & & \\
$\mathbf{X}_{\mathbf{1}}$ & 0,502 & 1,993 \\
$\mathbf{X}_{\mathbf{2}}$ & 0,511 & 0,1995 \\
$\mathbf{X}_{\mathbf{3}}$ & 0,692 & 0,1444
\end{tabular}

Sumber: Data yang diolah 2016

\section{Hasil Uji Hipotesis}

a. Pengaruh Persepsi Wajib Pajak tentang Penerapan PP No, 46 Tahun 2013 terhadap Kepatuhan Wajib Pajak.

$\mathrm{H}_{1}$ : Persepsi Wajib Pajak Tentang Penerapan PP No. 46 tahun 2013 berpengaruh positif dan signifikan terhadap Kepatuhan Wajib Pajak UMKM.

Tabel 6. Rangkuman Hasil Uji Hipotesis 1

\begin{tabular}{lccc}
\hline Variabel & $\begin{array}{c}\text { Koefisien } \\
\text { Regresi }\end{array}$ & t hitung & Sig \\
\hline Konstan & 17,253 & 2,980 & 0.004 \\
\hline $\mathbf{X}_{1}$ & 0,582 & 3,071 & 0,003 \\
\hline $\mathbf{R}$ & $\mathbf{0 , 3 0 3}$ & & \\
\hline$R$ Square & $\mathbf{0 , 0 9 2}$ & & \\
\hline
\end{tabular}

Sumber: Data primer diolah, 2016

Hasil penelitian mendukung hipotesis pertama bahwa variabel Persepsi Wajib Pajak Tentang Penerapan PP No. 46 Tahun 2013 berpengaruh positif dan signifikan terhadap Kepatuhan Wajib Pajak UMKM di Kota Yogyakarta. Hal ini ditunjukkan nilai koefisien regresi variabel bebas pertama sebesar 0,582 menyatakan bahwa setiap kenaikan sebesar 1 satuan akan meningkatkan kepatuhan wajib pajak sebesar 0,582 satuan. Nilai thitung $>\mathrm{t}$ tabel $(3,071>$ 1,66123) dengan signifikansi 0,003 lebih kecil dari 0,005 yang mengindikasikan 


\section{JURNAL NOMINAL / VOLUME V NOMOR 2 / TAHUN 2016}

bahwa Persepsi Wajib Pajak Tentang Penerapan PP No. 46 Tahun 2013 berpengaruh positif dan signifikan terhadap Kepatuhan Wajib Pajak.

Hasil penelitian ini menunjukkan nilai koefisisen determinasi $\mathrm{R}$ Square $\left(\mathrm{R}^{2}\right)$ sebesar 0,092. Hal ini berarti kepatuhan wajib pajak UMKM di Kota Yogyakarta dipengaruhi persepsi wajib pajak tentang penerapan PP No. 46 tahun 2013 hanya sebesar 9,2\%. Pengaruh tersebut tergolong rendah dikarenakan persepsi wajib pajak tentang penerapan PP No. 46 tahun 2013 kebanyakan negatif. Wajib pajak merasa bahwa penerapan PP No. 46 tahun 2013 tidak adil bagi mereka. Belum tentu mereka mendapatkan keuntungan dari usaha, tetapi tetap diwajibkan membayar pajak. Jadi, wajib pajak merasa dirugikan.

\section{b. Pengaruh Pemahaman Perpajakan terhadap Kepatuhan Wajib Pajak}

$\mathrm{H}_{2}$ : Pemahaman Perpajakan berpengaruh positif dan signifikan terhadap c. Kepatuhan Wajib Pajak UMKM.

Tabel 7. Rangkuman Hasil Uji Hipotesis 2

\begin{tabular}{lccc}
\hline Variabel & $\begin{array}{l}\text { Koefisien } \\
\text { Regresi }\end{array}$ & $\begin{array}{c}\mathbf{t} \\
\text { hitung }\end{array}$ & Sig \\
\hline Konstan & 13,284 & 3,589 & 0,001 \\
\hline $\mathbf{X}_{2}$ & 0,708 & 5,894 & 0,000 \\
\hline $\mathbf{R}$ & $\mathbf{0 , 5 2 2}$ & & \\
\hline $\boldsymbol{R}$ Square & $\mathbf{: 0 , 2 7 2}$ & & \\
\hline
\end{tabular}

Sumber: Data diolah, 2016

Hasil penelitian mendukung hipotesis kedua bahwa variabel Pemahaman
Perpajakan berpengaruh positif dan signifikan terhadap Kepatuhan Wajib Pajak UMKM di Kota Yogyakarta. Hal ini ditunjukkan nilai koefisien regresi variabel bebas pertama sebesar 0,708 menyatakan bahwa setiap kenaikan sebesar 1 satuan akan meningkatkan kepatuhan wajib pajak sebesar 0,708 satuan. Nilai t hitung $>\mathrm{t}$ tabel $(5,894>$ 1,66123) dengan signifikansi 0,000 lebih kecil dari 0,005 yang mengindikasikan bahwa Pemahaman Perpajakan berpengaruh positif dan signifikan terhadap Kepatuhan Wajib Pajak.

Hasil penelitian ini menunjukkan nilai koefisisen determinasi R Square $\left(\mathrm{R}^{2}\right)$ sebesar 0,272. Hal ini berarti kepatuhan wajib pajak UMKM di Kota Yogyakarta dipengaruhi pemahaman perpajakan sebesar 27,2\%. Hasil tersebut tinggi dikarenakan wajib pajak yang benar-benar paham terhadap perpajakan maka akan melaksanakan kewajiban perpajakannya sesuai dengan yang dipahami.

\section{Pengaruh Sanksi Perpajakan terhadap} Kepatuhan Wajib Pajak

d. $\mathrm{H}_{3}$ : Sanksi Perpajakan berpengaruh positif dan signifikan terhadap Kepatuhan Wajib Pajak UMKM.

Tabel 8. Rangkuman Hasil Uji Hipotesis 3

\begin{tabular}{lccc}
\hline Variabel & $\begin{array}{c}\text { Koefisien } \\
\text { Regresi }\end{array}$ & $\begin{array}{c}\mathbf{t} \\
\text { hitung }\end{array}$ & Sig \\
\hline Konstanta & 15,935 & 3,120 & 0,002 \\
\hline $\mathbf{X}_{3}$ & 1,066 & 3,746 & 0,000 \\
\hline $\mathbf{R}$ & $\mathbf{0 , 3 6 2}$ & & \\
\hline $\boldsymbol{R}$ Square & $\mathbf{0} \mathbf{0 , 1 3 1}$ & & \\
\hline
\end{tabular}

Sumber: Data diolah, 2016 


\section{JURNAL NOMINAL / VOLUME V NOMOR 2 / TAHUN 2016}

Hasil penelitian mendukung hipotesis ketiga bahwa variabel Sanksi Perpajakan berpengaruh positif dan signifikan terhadap Kepatuhan Wajib Pajak UMKM di Kota Yogyakarta. Hal ini ditunjukkan nilai koefisien regresi variabel bebas pertama sebesar 1,066 menyatakan bahwa setiap kenaikan sebesar 1 satuan akan meningkatkan kepatuhan wajib pajak sebesar 1,066 satuan. Nilai thitung > t tabel (3,746> 1,66123) dengan signifikansi 0,000 lebih kecil dari 0,005 yang mengindikasikan bahwa Sanksi Perpajakan berpengaruh positif dan signifikan terhadap Kepatuhan Wajib Pajak.

Hasil penelitian ini menunjukkan nilai koefisisen determinasi R Square $\left(\mathrm{R}^{2}\right)$ sebesar 0,131 . Hal ini berarti kepatuhan wajib pajak UMKM di Kota Yogyakarta dipengaruhi sanksi perpajakan hanya sebesar $13,1 \%$. Hasil ini tergolong rendah dikarenakan wajib pajak berpikir bahwa sanksi tidak ditegakkan secara tegas maka tidak membayar pajak tidak masalah. Dengan demikian, sanksi tidak terlalu berpengaruh terhadap kepatuhan wajib pajak.

\section{e. Pengaruh Persepsi Wajib Pajak tentang} Penerapan PP No. 46 Tahun 2013, Pemahaman Perpajakan, dan Sanksi Perpajakan terhadap Kepatuhan Wajib Pajak.

\section{$\mathrm{H}_{4}$ : Persepsi Wajib Pajak Tentang} Penerapan PP No. 46 tahun 2013, Pemahaman Perpajakan, dan Sanksi
Perpajakan secara bersama-sama berpengaruh positif dan signifikan terhadap Kepatuhan Wajib Pajak UMKM.

Tabel 20. Rangkuman Hasil Uji Hipotesis 4

\begin{tabular}{ll}
\hline Keterangan & Koefisien Regresi \\
\hline Konstanta & 12,310 \\
\hline $\mathbf{X}_{\mathbf{1}}$ & 0,278 \\
\hline $\mathbf{X}_{\mathbf{2}}$ & 0,726 \\
\hline $\mathbf{X}_{\mathbf{3}}$ & 0,497 \\
\hline $\mathbf{R}$ Square $=\mathbf{0 , 2 9 6}$ & \\
F Hitung $=\mathbf{1 2 , 7 6 1}$ & \\
Sig $\mathbf{F} \quad \mathbf{0 , 0 0 0}$ & \\
&
\end{tabular}

Sumber: Data diolah, 2016

Hasil penelitian mendukung hipotesis keempat Persepsi Wajib Pajak Tentang Penerapan PP No,46 Tahun 2013, Pemahaman Perpajakan, dan Sanksi Perpajakan secara bersama-sama berpengaruh positif dan signifikan terhadap kepatuhan wajib pajak UMKM di Kota Yogyakarta. Hal ini ditunjukkan hasil uji regresi berganda dengan koefisien regresi untuk variabel Persepsi Wajib Pajak Tentang Penerapan PP No, 46 Tahun 2013 memberikan nilai koefisien 0,278 , variabel Pemahaman Perpajakan memberikan nilai 0,726, dan variabel Sanksi Perpajakan memberikan nilai 0,497 yang berarti mempunyai nilai positif. Jadi semakin tinggi Persepsi Wajib Pajak Tentang Penerapan PP No, 46 Tahun 2013, Pemahaman Perpajakan, Sanksi Perpajakan maka akan semakin tinggi pula Kepatuhan Wajib Pajak. Nilai F hitung sebesar 12,761 > F tabel 1,66123 dengan signifikansi 0,000 maka dapat disimpulkan bahwa Persepsi Wajib Pajak Tentang Penerapan PP No, 46 Tahun 2013, 


\section{JURNAL NOMINAL / VOLUME V NOMOR 2 / TAHUN 2016}

Pemahaman Perpajakan, Sanksi Perpajakan berpengaruh signifikan terhadap kepatuhan wajib pajak.

Persepsi wajib pajak merupakan suatu proses wajib pajak mengorganisasi, menginterpretasi, mengalami, dan mengolah isyarat atau materi yang diterima dari lingkungan luar seperti peraturan baru. Penerapan PP No. 46 tahun 2013 diharapkan dapat meningkatkan kepatuhan wajib pajak. Hal ini dikarenakan, peraturan ini telah menyederhanakan tarif pajak berdasarkan pajak final $1 \%$ atas peredaran bruto. Peraturan yang sederhana dapat meningkatkan kepatuhan wajib pajak karena memudahkan wajib pajak dalam menghitung, membayar, dan melaporkan pajak. Persepsi wajib pajak terhadap PP No. 46 tahun 2013 diharapkan sama dengan tujuan yang tercantum PP No. 46 sehingga dapat meningkatkan kepatuhan wajib pajak.

Pemahaman menunjukkan seberapa mengerti seseorang terhadap sesuatu. Apabila wajib pajak memahami perpajakan, hal ini ini akan meningkatkan kepatuhan wajib pajak. Sebaliknya, jika wajib pajak tidak memahami perpajakan maka wajib pajak akan cenderung tidak mematuhi kewajiban perpajakannya.

Sanksi merupakan suatu hukuman yang dikenakan bagi seseorang yang tidak mematuhi peraturan. Sanksi dapat memotivasi wajib pajak untuk patuh karena wajib pajak berpikir bahwa sanksi pajak akan semakin merugikan wajib pajak. Adanya sanksi perpajakan dapat meningkatkan kepatuhan wajib pajak. Berdasarkan uraian di atas, Persepsi Wajib Pajak Tentang Penerapan PP No. 46 tahun 2013, Pemahaman Perpajakan, dan Sanksi Perpajakan secara bersama-sama akan berpengaruh positif dan signifikan terhadap Kepatuhan Wajib Pajak UMKM.

\section{SIMPULAN DAN SARAN}

\section{Simpulan}

a. Persepsi wajib pajak tentang penerapan PP No. 46 tahun 2013 berpengaruh positif dan signifikan terhadap kepatuhn wajib pajak UMKM di Kota Yogyakarta. Hal ini dapat dilihat dari nilai koefisian regresi yang bernilai positif sebesar 0,582 . Nilai $\mathrm{t}$ hitung $>\mathrm{t}$ tabel $(3,071>1,66123)$ dengan signifikansi 0,003 lebih kecil dari 0,005. Hal ini mengindikasikan bahwa Persepsi Wajib Pajak Tentang Penerapan PP No. 46 Tahun 2013 yang semakin baik maka Kepatuhan Wajib Pajak akan semakin naik pula.

b. Pemahaman Perpajakan berpengaruh positif dan signifikan terhadap kepatuhn wajib pajak UMKM di Kota Yogyakarta. Hal ini dapat dilihat dari nilai koefisian regresi yang bernilai positif sebesar 0,708 . Nilai $\mathrm{t}$ hitung $>\mathrm{t}$ tabel $(5,894>1,66123)$ dengan signifikansi 0,000 lebih kecil dari 0,005 


\section{JURNAL NOMINAL / VOLUME V NOMOR 2 / TAHUN 2016}

Hal ini mengindikasikan bahwa Pemahaman Perpajakan yang semakin baik maka Kepatuhan Wajib Pajak akan semakin naik pula.

c. Sanksi Perpajakan berpengaruh positif dan signifikan terhadap kepatuhan wajib pajka UMKM di Kota Yogyakarta. Hal ini dapat dilihat dari nilai koefisian regresi yang bernilai positif sebesar 1,066. Nilai $\mathrm{t}$ hitung > t tabel $(3,746>$ 1,66123) dengan signifikansi 0,000 lebih kecil dari 0,005 Hal ini mengindikasikan bahwa Sanksi Perpajakan yang semakin baik maka Kepatuhan Wajib Pajak akan semakin naik pula.

d. Persepsi Wajib Pajak Tentang Penerapan PP No. 46 Tahun 2013, Pemahaman Perpajakan, dan Sanksi Perpajakan secara bersama-sama berpengaruh positif dan signifikan terhadap Kepatuhan Wajib Pajak UMKM di Kota Yogyakarta. Hal ini ditunjukkan hasil Nilai F hitung sebesar 12,761 > F tabel 1,66123 dengan signifikansi $0,000<0,005$. Hasil uji regresi berganda dengan koefisien regresi untuk variabel Persepsi Wajib Pajak Tentang Penerapan PP No, 46 Tahun 2013 memberikan nilai koefisien 0,278, variabel Pemahaman Perpajakan memberikan nilai 0,726 , dan variabel Sanksi Perpajakan memberikan nilai 0,497 yang berarti mempunyai nilai positif. Jadi, semakin tinggi Persepsi Wajib Pajak Tentang Penerapan PP No. 46 Tahun 2013, Pemahaman Perpajakan, dan Sanksi Perpajakan maka akan semakin tinggi pula Kepatuhan Wajib Pajak UMKM di Kota Yogyakarta.

\section{Saran}

a. Bagi Pemerintah

1) Pemerintah sebagai pembuat regulasi atau peraturan mengenai perpajakan, selain pemubuat regulasi pemerintah seharusnya meninjau apakah peraturan yang baru dipatuhi oleh semua sasaran. Hal ini dilakukan agar kepatuhan wajib pajak semakin meningkat dan memberikan penerimaan pajak yang lebih tinggi.

2) Pemerintah harus meningkatkan sosialisasi perpajakan mengenai tarif pajak dan ketentuan-ketentuan perpajakan yang berlaku di Indonesia sehingga pemahaman wajib pajak tentang perpajakan masyarakat semakin meningkat.

3) Sanksi perpajakan harus ditingkatkan untuk disosialisasikan dengan baik kepada wajib pajak agar wajib pajak dapat memahami hal-hal yang berkaitan dengan pelaksanaan sanksi perpajakan serta penyebab-penyebab dikenakannya suatu sanksi perpajakan terhadap wajib pajak. Selain itu pemerintah juga harus menegakkan sanksi secara tegas. 


\section{JURNAL NOMINAL / VOLUME V NOMOR 2 / TAHUN 2016}

a. Bagi Wajib Pajak

Wajib pajak seharusnya sadar untuk memenuhi kewajiban perpajakannya karena hal itu akan kembali pada wajib pajak walaupun tidak secara langsung. Wajib pajak juga harus mengetahui regulasi-regulasi terbaru dari perpajakan karena mungkin wajib pajak akan mendapat keuntungan dari regulasi tersebut.

b. Bagi Peneliti Selanjutnya

1) Bagi peneliti selanjutnya yang tertarik untuk melakukan kajian di bidang yang sama dapat menambah variabel independen maupun dependen yang memiliki kemungkinan pengaruh terhadap hubungan persepsi wajib pajak tentang penerapan PP No. 46 tahun 2013, pemahaman perpajakan, sanksi perpajakan, dan kepatuhan wajib pajak atau dapat menggunakan variabel-variabel yang tidak digunakan dalam penelitian ini, sehingga dapat ditemukan variabel baru yang akan meningkatkan kepatuhan wajib pajak.

2) Pada penelitian selanjtutnya sebaiknya jumlah populasi serta sampel ditambah dan diperluas sehingga penelitian dapat digeneralisasikan secara baik.

\section{DAFTAR PUSTAKA}

Adam Ibrahim Indrawijaya. (2010). Teori, Perilaku, dan Budaya Organisasi. Bandung: Refika Aditama.

Adi Ratno Pamuji, dkk. (2014). "Faktorfaktor yang Mempengaruhi Kepatuhan Pemilik Usaha Mikro, Kecil, dan Menengah (UMKM) dalam Memenuhi Kewajiban Perpajakan (Studi pada Wajib Pajak Pemilik UMKM di KPP Pratama Malang Selatan)". Jurnal. Jurusan Administrasi Bisnis Universitas Brawijaya.

Arabella Oentari Fuadi dan Yenni Mangoting. (2013). "Pengaruh Kualitas Pelayanan Petugas Pajak, Sanksi Perpajakan, dan Biaya Kepatuhan Pajak Terhadap Kepatuhan Wajib Pajak UMKM". Tax \& Accounting Review, Vol. 1, No. 1, 2013.

Arfan Ikhsan Lubis. (2011). Akuntansi Keperilakuan. Edisi 2. Jakarta: Salemba Empat.

Bryan Wahyu Rahmanto. (2015). "Pengaruh Pemahaman Peraturan Pajak, Sanksi Denda, dan Kesadaran Wajib Pajak, terhadap Kepatuhan Wajib Pajak Orang Pribadi di Kantor Pelayanan Pajak Pratama Yogyakarta Pada Tahun 2014”. Skripsi. Jurusan Akuntansi Fakultas Ekonomi Universitas negeri Yogyakarta.

Burhan Bungin. (2009). Metodologi Penelitian Kuantitatif: Komunikasi, Ekonomi, dan Kebijakan Publik Serta Ilmu-Ilmu Sosial Lainnya. Jakarta: Kencana.

Chaizi Nasucha. (2004). Reformasi Administrasi Publik: Teori dan Praktek. Jakarta: PT Gramedia Widiasarana Indonesia. 


\section{JURNAL NOMINAL / VOLUME V NOMOR 2 / TAHUN 2016}

Disperindagkop Kota Yogyakarta. jumlah umkm diakses dari umkm.jogjakota.go.id.

Departemen Pendidikan Nasional. (2008). Kamus Besar Bahasa Indonesia Edisi 4. Jakarta: Gramedia Pustaka Utama.

Direktorat Jenderal Pajak. (2013). Leaflet Pajak Wajib Pajak yang Memiliki Peredaran Bruto Tertentu (PP No. 46 Tahun 2013). Diakses dari www.pajak.go.id.

Gandhys Resyniar. (2014). "Persepsi Pelaku Usaha Mikro Kecil Menengah (UMKM) terhadap Penerapan PP No. 46 tahun 2013". Jurnal Ekonomi.

Hana Pratiwi Burhan. (2015). "Pengaruh Sosialisasi Perpajakan, Pegetahuan Perpajakn, Persepsi Wajib Pajak Tentang Sanksi Pajak dan Implementasi PP No. 46 Tahun 2013 Terhadap Kepatuhan Wajib Pajak Orang Pribadi (Studi Empisris pada Wajib Pajak di Kabupaten Banjarnegara)". Skripsi. Fakultas Ekonomika dan Bisnis: Universitas Diponegoro.

Husein Umar. (2011). Metode Penelitian untuk Skripsi dan Tesis Bisnis. Jakarta: PT Raja Grafindo Persada.

Imam Ghozali. (2011). Aplikasi Analisis Multivariate denga Program IBM SPSS 19. Edisi ke 5. Semarang: Badan Penerbit Universitas Diponegoro.

John Hutagaol, Wing Wahyu, Arya Pradipta. (2007). Strategi Meningkatkan Kepatuhan Wajib Pajak. Jurnal Akuntabilitas, Hal. 186-193.

Mardiasmo. (2003). Perpajakan. Yogyakarta : Andi offset

(2009). Perpajakan Edisi Revisi. Yogyakarta: Andi.
Maya Saptiani,dkk. (2014). "Pengaruh Administrasi, Sosialisasi, dan Implementasi Peraturan Pemerintah Nomor 46 Tahun 2013 Terhadap Kepatuhan Wajib Pajak dalam Membayar Pajak UKM (Studi Kasus: KPP Pratama Ilir Barat I Palembang)". Jurnal. STIE MDP Palembang.

Nur Indriantoro dan Bambang Supomo. (1999). Metode Penelitian Bisnis. Yogyakarta: BPFE

Okezone. (2015). "UKM Dominasi Penerimaan Pajak di DIY". Diambil dari

http://economy.okezone.com/read/201 5/02/10/20/1103723/ukm-dominsipenerimaan -pajak-di-yogyakarta pada tanggal 23 Juni 2015.

Peraturan Menteri Keuangan Republik Indonesia Nomor 192/PMK.03/2007 Pasal 1 tentang Kepatuhan Wajib Pajak.

Republik Indonesia. Undang-Undang Nomor 28 Tahun 2007 tentang Perpajakan.

Republik Indonesia. Undang-Undang Nomor 28 Tahun 2007 tentang Perubahan Ketiga atas Undang-Undang Nomor 6 Tahun 1983 tentang Ketentuan Umum dan Tata Cara Perpajakan.

Saifuddin Azwar. (2013). Reliabilitas dan Validitas Edisi 4. Yogyakarta: Pustaka Pelajar.

Siti Kurnia Rahayu. (2010). Perpajakan Indonesia. Yogyakarta: Graha Ilmu.

Sony Devano dan Siti Karunia Rahayu. (2006). Perpajakan: Konsep, Teori, dan Isu. Jakarta: Prenada Media Group.

Sri Putri Tita Mutia. (2014). "Pengaruh Sanksi Perpajakan, Kesadaran Wajib Pajak, Pelayanan Fiskus, dan Tingkat Pemahaman Wajib Pajak Terhadap 
Kepatuhan Wajib Pajak Orang Pribadi” (Studi Empiris pada Wajib Pajak Orang Pribadi yang terdaftar di KPP Pratama Padang)". Artikel Ilmiah. Program Studi Akuntansi Universitas Negeri Padang.

Sri Rustiningsih. (2011). "Faktor-faltor yang Mempengaruhi Kepatuhan Wajib Pajak". Jurnal Widya Warta No. 02 Tahun XXXV.

Sugiyono. (2008). Statistika untuk Penelitian. Bandung: Alfabeta. . (2011). Metode Penelitian Kombinasi (Mixed Methods). Bandung: Alfabeta.

. (2012). Statistika Untuk Penelitian. Bandung: Alfabeta.

Suharsimi Arikunto. (2009). Dasar-Dasar Evaluasi Pendidikan (edisi revisi). Jakarta: Bumi Aksara. . (2010). Prosedur Penelitian Suatu Pendekatan Praktik. Jakarta: PT Rineka Cipta.

Sukrisno Agoes dan Estralita Trisnawati. (2007). Akuntansi Perpajakan. Jakarta: Salemba Empat.

TribunJogja. (2016). "Optimalisasi Penerimaan Wajib Pajak dari UMKM". Diambil dari http://jogja.tribunnews.com/2016/01/0 3/optimalisasi-penerimaan-wajibpajak-dari-umkm-dilirik pada tanggal 17 Januari 2016.

Uma Sekaran. (2007). Metode Penelitian Untuk Bisnis. Jakarta: Salemba Empat.

Waluyo. (2004). Perpajakan di Indonesia. Jakarta. Salemba Empat. 